\title{
Status of the Endangered Egyptian vulture Neophron percnopterus in the Cantabrian Mountains, Spain, and assessment of threats
}

\author{
Patricia Mateo-Tomás, Pedro P. Olea and Is idoro Fombellida
}

\begin{abstract}
The Egyptian vulture Neophron percnopterus is categorized as Endangered on the IUCN Red List, as well as on the European and Spanish Red Lists. Spain is home to the most important breeding population of Egyptian vultures in Europe but this population has differing trends at a regional scale. We present data for the Egyptian vulture population in the Cantabrian Mountains, north-west Spain, during the last 3 decades and assess the main threats to the species there. The Egyptian vulture population in the Cantabrian Mountains was estimated to be 175 breeding pairs in 2008, which comprised 13-14\% of the Spanish population. This population has been stable, or increasing slightly, since 2000. During 2000-2008 4.3\% of the Cantabrian Egyptian vulture population was affected by the use of illegal poison. During the same period the number of sheep and goats reared (which contributes to the maintenance of Egyptian vulture territories) was reduced by $27.4 \%$, which could lead to food shortages for the vultures in the near future. Currently 32 breeding pairs (18.3\% of the population) have wind turbines within their foraging areas, with an average of 59 wind turbines per territory (range 1-176). During the next few years this number will increase to 110 turbines per territory within 69 vulture territories $(39.4 \%$ of the population). Nearly a third (32.6\%) of breeding territories are located outside protected areas. Better coordination between administrative areas is needed to guarantee the conservation of the Cantabrian Mountains population of Egyptian vultures through effective surveillance and protection in the numerous existing protected areas.
\end{abstract}

Keywords Cantabrian Mountains, Egyptian vulture, illegal poisoning, Neophron percnopterus, population status, wind turbines

\section{Introduction}

The Egyptian vulture Neophron percnopterus is a terri1 torial, cliff-nesting raptor distributed from the Medi-

Patricia Mateo-Tomás (Corresponding author) Department of Biodiversity and Environmental Management, Faculty of Biological and Environmental Sciences, University of León, Campus de Vegazana, 24071, León, Spain. E-mail pmatt@unileon.es

Pedro P. Olea School of Biology, IE University, Segovia, Spain

Isidoro Fombellida Mustela S.C., Consultores en Recursos Naturales, Torrelavega, Spain

Received 2 April 2009. Revision requested 26 June 2009.

Accepted 13 August 2009. terranean countries to India and also occupying areas in the east and south of Africa. Formerly categorized as Least Concern on the IUCN Red List the species has recently been upgraded to Endangered (BirdLife International, 2008a) because of its rapid population decline in India (up to $35 \%$ annually during 2000-2003; Cuthbert et al., 2006) and Europe $(>50 \%$ over the last three generations; BirdLife International, 2008a).

In Europe, where there are 3,300-5,050 breeding pairs, the Egyptian vulture is also categorized as Endangered (BirdLife International, 2004). The threats to the species are poisoning, human persecution and disturbance, loss of suitable habitat, collisions with power lines and wind farms, and reduced food availability (BirdLife International, 2008b). In Spain, which contains $82 \%$ of the European population, the species is categorized as Endangered because of a population decline of c. $25 \%$ detected over $1987-2000$ (Donázar, 2004). However, the species exhibits differing population trends in different parts of the country. In some areas declines of up to $60 \%$ have been described during the last 2 decades (in the Ebro valley, Navarra: Del Moral \& Martí, 2002; Cortés-Avizanda et al., 2009), whereas population increases have been reported in other regions over the same period (COA, 2004; García-Ripollés \& LópezLópez, 2006). Some of the increases could be an artefact of improved monitoring techniques (Donázar, 2004) but could also be because of the presence of extensive livestock activity in some areas (Donázar, 2004), which has been shown to be crucial for maintaining the species' territories in mountainous areas (Mateo-Tomás \& Olea, 2010). The populations that show stable or increasing trends may be key for the species' conservation within a metapopulation context.

Here we examine the status, population trends and breeding parameters of the Egyptian vulture population in the western and central Cantabrian Mountains. This region accounts for c. $20 \%$ of the total Spanish population (Del Moral \& Martí, 2002). We also assess the main threats to the species (poisoning, human disturbance, reduced food availability and wind farms; BirdLife International, 2008b) in this Cantabrian population.

\section{Study area}

The Egyptian vulture is widespread in the Iberian Peninsula but it is absent from areas that are topographically uniform or that have a dry climate. We studied Egyptian vultures in 
four regions in north-west Spain: Asturias, western Cantabria, León and Palencia (Fig. 1). This area extends over $15,500 \mathrm{~km}^{2}$. The central part of the studied area is characterized by the presence of high, rocky mountains (up to $2,648 \mathrm{~m}$ ) and the western portion contains both high, rocky mountains and areas of lower altitude, mainly dominated by forests. The Egyptian vultures in this area are at the north-western edge of their distribution in Spain and Europe (Fig. 1). Breeding pairs arrive from their winter range in Africa during early March and remain in their breeding territories until mid September, rearing one or two chicks. A territory is generally used year after year and is actively defended by its occupants (Donázar, 1993).

\section{Methods}

Data on the historical distribution of the Egyptian vulture population in the study area were gathered from previous censuses (Perea et al., 1990; Benito et al., 1997; Jubete, 1997; Del Moral \& Martí, 2002; COA, 2004; Picos de Europa National Park, pers. comm.; authors, unpubl. data). Upto-date data were obtained from Del Moral (2009) and from field surveys in 2008 (Fombellida et al., 2008). The censuses consisted of visiting areas that could be suitable for the species (i.e. areas with rocky cliffs) between March and August. Visits included inspection of the cliffs using binoculars and telescopes on days with good visibility. The mean number of visits per territory varied between the different censuses, from a mean of $3 \pm \mathrm{SE}$ o to $6 \pm \mathrm{SE} 2$ ). The Egyptian vulture breeding territories were classified according to the amount of evidence for the occurrence of breeding following the terminology proposed by Martí \& Del Moral (2003).

\section{Data analysis}

The study area was divided into four sectors according to regional boundaries because most available data were obtained from regional censuses (Fig. 1, Table 1). These sectors are: (1) NW, Asturias province, monitored in 1988, 1991, 1996, 2000, 2004 and 2008, (2) NE, western Cantabria province, monitored in 1988, 2000 and 2008, (3) SW, León province, monitored in 1988, 2000 and 2008, and (4) SE, Palencia province, monitored in 1988, 1997, 2000 and 2008.

The population trend was calculated as the variation (\%) in the number of breeding pairs between different time periods (Del Moral \& Martí, 2002). In the SW and SE sectors of the area, where the censuses were sufficient (mean $=6$ visits per territory per year; $n=394$ ) to identify territory occupation with a high probability ( $95 \%$; authors, unpubl. data), we estimated the percentage of new (or not previously detected) and abandoned territories for 20002008. Accordingly, we considered a territory abandoned if it had been occupied previously but if in 2008 we did not detect Egyptian vultures within the home range $(2.5 \mathrm{~km}$; Mateo-Tomás \& Olea, 2009, 2010).

Only those pairs that were adequately monitored throughout the breeding season were used to calculate the breeding parameters: productivity (number of fledglings/number of monitored pairs), breeding success (number of fledglings/ number of incubating pairs) and flight rate (number of fledglings/number of pairs with fledglings; Del Moral \& Martí, 2002). When the census methodologies were similar, we compared breeding parameters using Kruskal-Wallis and Wilcoxon signed rank tests.

We evaluated the threats that are considered critical or important according to the Species Action Plan for the Egyptian vulture in the European Union (BirdLife

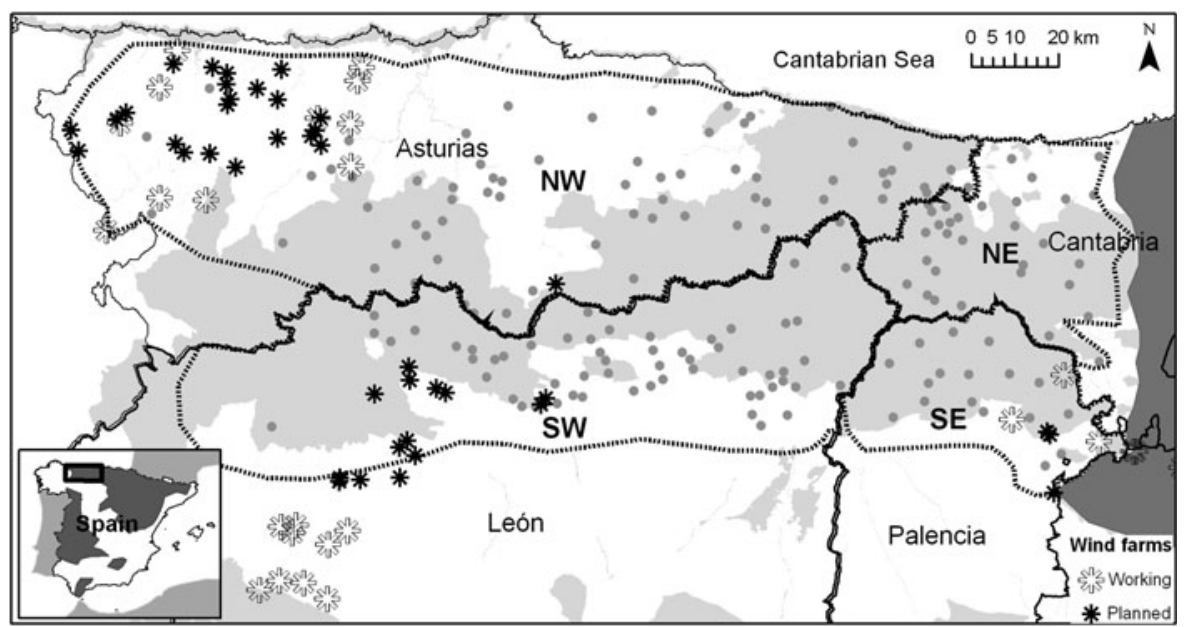

FIG. 1 The study area in the Cantabrian Mountains of north-west Spain. The grey dots are Egyptian vulture Neophron percnopterus territories. The solid black lines represents administrative boundaries and the dashed lines the limits of the NW, NE, SW and SE sectors (both lines overlap partially). Protected areas are shown in grey. Locations of the wind farms currently working and those approved for construction within the next few years are also shown. The dark shaded area on the inset shows the species' breeding range in Spain (Del Moral \& Martí, 2002) and the rectangle the location of the main figure. 
TABLE 1 Breeding parameters (mean \pm SD) of Egyptian vulture Neophron percnopterus populations in the Italian Peninsula and in various regions of Spain. Sample sizes (equivalent to mean number of monitored pairs per year \pm SD) are given in parentheses.

\begin{tabular}{llcccl}
\hline Region & Period & Productivity & Breeding success & Flight rate & Reference \\
\hline $\begin{array}{l}\text { Italian } \\
\quad \text { Peninsula }\end{array}$ & $1984-1999$ & & $0.99 \pm 0.66(10 \pm 2)$ & $1.27 \pm 0.45(10 \pm 2)$ & $\begin{array}{l}\text { Liberatori \& } \\
\text { Penteriani }(2001)\end{array}$ \\
$\begin{array}{l}\text { Ebro Valley } \\
\text { Spain }\end{array}$ & $1999-2005$ & $0.98(15 \pm 0)$ & & Grande $(2006)$ \\
Segovia & 2000 & $0.88(1,100)$ & $1.03(1,100)$ & $1.19(1,100)$ & $\begin{array}{l}\text { Del Moral \& Martí (2002) } \\
\text { Castellón }\end{array}$ \\
& 2000 & $0.70(11)$ & $1.40(11)$ & $1.40(11)$ & WWF/Adena (2008) \\
Segovia & $2003-2005$ & $0.91 \pm 0.08(11 \pm 1)$ & $0.76 \pm 0.07(11 \pm 1)$ & $1.20 \pm 0.09(11 \pm 1)$ & García-Ripollés \& \\
Study area & $2005-2007$ & $0.88 \pm 0.22(9 \pm 0)$ & $1.08 \pm 0.07(9 \pm 0)$ & $1.36 \pm 0.19(9 \pm 0)$ & Wópez-López (2006) \\
Study area (NW) & 2000 & $0.67(73)$ & $0.93(73)$ & $1.09(73)$ & Del Moral \& Martí (2002) \\
Study area & 2008 & $0.87(45)$ & $0.89(45)$ & $1.00(45)$ & 3rd National Census \\
$\quad$ SW \& SE) & 2008 & $1.04(33)$ & $1.10(33)$ & $1.17(33)$ & This study
\end{tabular}

International, 2008b). Poisoning data for 2000-2008 were obtained from the Antidoto Program database (WWFADENA, 2008). The total number of poisoning events was computed for the Egyptian vulture and for other scavenging birds (including griffon vulture Gyps fulvus, kites Milvus sp. and corvids), non-scavenging birds and mammals.

Reduced food availability is considered a critical threat for the species (BirdLife International, 2008b), and extensive livestock (i.e. free-ranging cows, sheep and goats at low stocking densities) is key for the presence of Egyptian vulture territories in the study area (Mateo-Tomás \& Olea, 2009, 2010). We used data from regional and national government databases to calculate the current density of livestock units (LU) in the study area $(1$ cow/horse $=5 \mathrm{LU}$, 1 sheep/goat $=1$ LU; Olea \& Mateo-Tomás, 2009) per

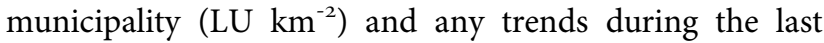
decade. To collect data on the removal of livestock carcasses we gave questionnaires to local and transhumant shepherds $(n=97)$ and to five veterinary units in 2005-2008. We interviewed 85 shepherds ( $55 \%$ of those in the area) and 12 cowherds ( $2 \%$ of those in the area). We obtained information about the removal of livestock carcasses for $>50 \%$ of the cow breeders $(n=625)$ through the official databases of the veterinary units.

Collision with wind turbines is an emerging threat to Egyptian vultures (BirdLife International, 2008b; Carrete et al., 2009). We calculated the number of wind turbines that have been established in the study area and the number that will become established over the next few years. To assess the potential impact of these structures on the conservation of the studied population we calculated the number of breeding territories that have wind turbines located within a radius of $25 \mathrm{~km}$ (reported as the maximum foraging distance from the nest for Egyptian vultures; Bergier \& Cheylan, 1980).

Disturbance by human activities and habitat degradation are also threatening the Egyptian vulture (Carrete et al., 2007; Zuberogoitia et al., 2008). To analyse the possible impact of these threats on the conservation of the species we calculated the percentage of breeding territories within and outside Natura 2000 protected areas (Sites of Community Importance and Special Protection Areas).

\section{Results}

An estimated 87 Egyptian vulture breeding pairs were in the study area in 1987-1988, 153 in 2000 and 175 in 2008 (Fig. 2a,b). In three of the four sectors (NW, NE and SW) the population grew slightly in the last decade, with annual increases of $1-2 \%$ (Fig. $2 \mathrm{~b}$ ). In contrast, the population trend in the SE sector showed a decrease of 1-2\% annually in the last decade (Fig. 2b).

Between 2000 and 2008 seven territories were abandoned in the SW sector (13.0\% of the territories in 2000) and two territories were abandoned in the SE (9.1\%). Seventeen breeding territories not detected in the 2000 census were registered as occupied in the SW and SE sectors in $2008(22.1 \%$ of the territories located in the SW and SE sectors). Sixteen of these new breeding territories were located in the SW sector and only one in the SE sector.

The breeding parameters calculated in 2000 did not differ significantly between those regions with available data (NW, NE and SW; Kruskal-Wallis test, $\mathrm{P}>0.05$ ). In addition, no significant differences were found in the breeding parameters between the SW and SE sectors in 2008 (Wilcoxon test, $\mathrm{P}>0.05$ ). We could only compare the breeding parameters between different time periods in the NW sector, where the census methods were similar over the last 2 decades. No significant differences were found (Wilcoxon test, $\mathrm{P}>0.05$ ). The breeding parameters of the Egyptian vulture in the study area are similar to those reported for other regions (Table 1 ).

\section{Conservation threats}

One hundred poisoning events were reported in the study area during 2000-2008. These affected 201 individuals of 20 

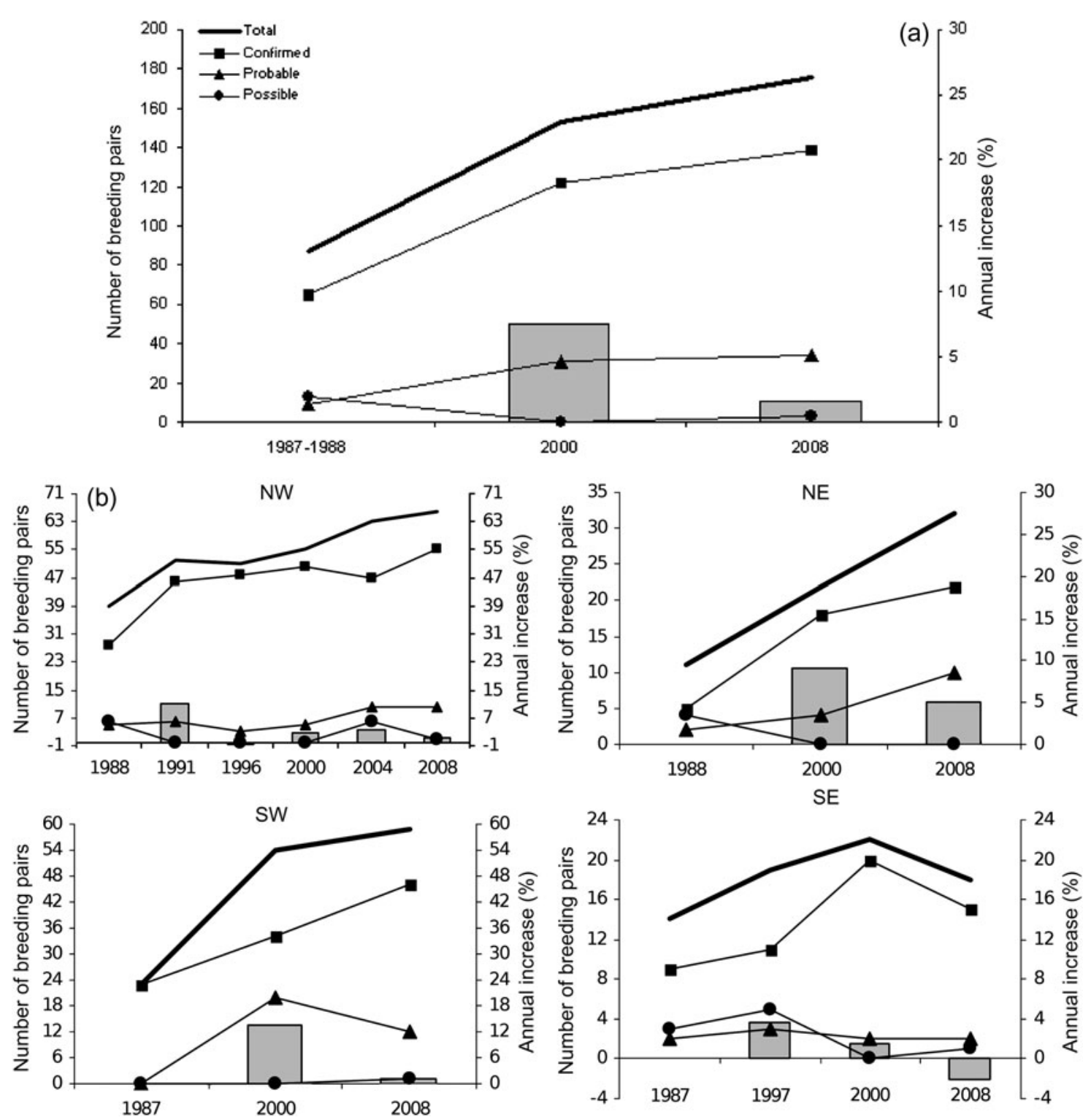

FIG. 2 Changes in the number of Egyptian vulture breeding pairs (a) during the last 3 decades in the study area (Fig. 1) and (b) in each sector (Fig. 1). Note the different y-axis scales in (b). The grey bars show the annual rate of increase.

different species, including 15 Egyptian vultures (7.5\%; Fig. 3). Scavenging birds were the most affected guild, with $53.7 \%$ of the dead individuals belonging to this group (Fig. 3). The SE sector accounted for $43.1 \%$ of the dead animals and 35

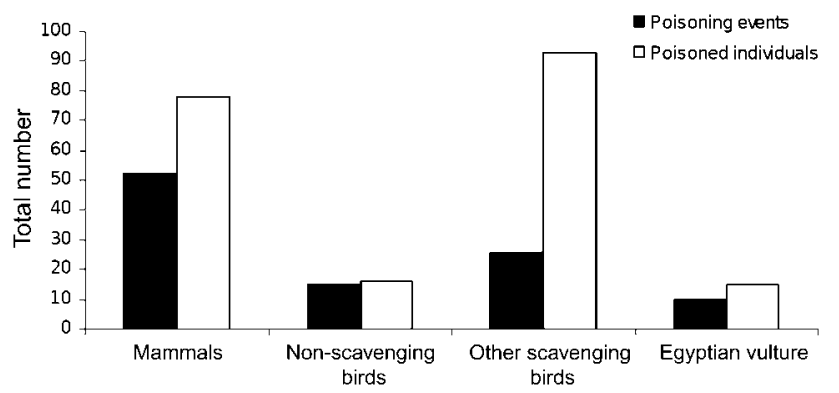

FIG. 3 Numbers of poisoning events and poisoned individuals of Egyptian vultures and other species in the study area (Fig. 1). poisoning events $\left(0.021 \mathrm{~km}^{-2}\right)$. This sector had also the highest number of poisoned Egyptian vultures (six) and $49.1 \%$ of the poisoned scavenging birds. The sector with the fewest reported poisoning events was the NE $\left(0.003 \mathrm{~km}^{-2}, \mathrm{n}=5\right)$.

There are currently 19 working wind farms with 490 turbines in the study area (Fig. 1) and 32 Egyptian vulture territories (18.3\% of the population) contain wind turbines within their foraging areas (mean $59 \pm$ SE 8; range 1-176). There are an additional 40 wind farms that have been approved (1,138 turbines; Fig. 1), which will increase the number of territories that overlap with wind turbines by $116 \%$ (i.e. 69 territories in total). Three new wind farms will be located in areas densely populated with Egyptian vultures (Fig. 1). The mean number of turbines per affected territory will increase by $147 \%$, to $110 \pm$ SE 16 turbines per territory (range 1-707). This increase will be most noticeable in the 
SW sector (61\% more turbines per territory) and will be smaller in the SE and NE sectors (4-13\%).

The mean number of livestock units per municipality in the study area in 2008 was $123 \pm \mathrm{SE} 13 \mathrm{~km}^{-2}$, which represents a decline in livestock density of $13.6 \%$ in the last 10 years. The decrease has been greater for sheep and goats (27.4\%) than for cows (6.9\%). However, there are different trends between sectors. The number of cows increased by $15.2 \%$ in the last decade in the NW and SW sectors, particularly in the SW sector ( $134 \%$ increase). In contrast, the number of sheep and goats decreased in all sectors by $21-36 \%$. Interviews with shepherds and veterinary authorities indicated that while only $20 \%$ of sheep and goat carcasses are removed from the field, 50\% of cow carcasses are removed.

A total of $118(67.4 \%)$ of the 175 Egyptian vulture territories in the study area were inside Natura 2000 protected areas. More than half (56.6\%) of the breeding territories were within Special Protection Areas, protected sites classified in accordance with the EU Wild Birds Directive (79/409/EEC). The SE sector had a significantly greater number of Egyptian vulture breeding territories within Special Protection Areas (83.3\%; Fisher's exact test, $\mathrm{P}<0.05$ for all comparisons).

\section{Discussion}

\section{Population status}

The estimated Egyptian vulture population in the study area was 175 breeding pairs in 2008, which equates to $13-$ $14 \%$ of the Spanish population (BirdLife International, 2008 b). This represents a slight annual increase (1.6\%) over the previous census in 2000 (Fig. 2; Del Moral \& Martí, 2002). However, this increase could be an artefact of better censusing techniques (Donázar, 2004), and the high annual population increase (7.6\%) detected during 1987-2000 was probably due to incomplete monitoring in 1987-1988 (Del Moral \& Martí, 2002). Moreover, up to $25 \%$ of occupied territories could remain undetected in the study area when performing the three visits per territory recommended by the Egyptian Vulture National Census (authors, unpubl. data). During the intensive census that we carried out on the south slope of the study area, for example, we detected 17 new territories that could have been undetected in the previous census, representing $22 \%$ of the territories located in 2000.

In the SW sector the population increased by $0.15 \%$ annually during the last decade. Although this increase could be due in part to previous detection errors (see above), a slight increase was also observed during the last decade in the NW sector (Fig. 2) where good coverage (four visits per territory) and high census frequency (Fig. 2b) provide high quality data. Therefore, the inferred trend for the studied population as a whole could be considered stable or slightly increasing. Nonetheless, it is necessary to implement efficient monitoring, with good coverage and frequency of censuses, to determine the real trend of this important population.

\section{Conservation threats}

Poisoning has been highlighted as one of the main threats to the Egyptian vulture in Europe (BirdLife International, 2008b), and Spain is no exception (Hernández \& Margalida, 2009). In our study area 15 Egyptian vultures were found poisoned in 2000-2008 (Fig. 3), representing $4.3 \%$ of the current breeding population. This percentage is considerably lower than those reported in other areas for the same period (e.g. $45.5 \%$ in Hoces del Riaza and $30.4 \%$ in Bárdenas Reales; WWF/Adena, 2008; Cortés-Avizanda et al., 2009). The density of poisoned Egyptian vultures registered in the study area in the last decade (0.0001 year ${ }^{-1} \mathrm{~km}^{-2}$ ) was considerably lower (64-140 times) than densities reported in other regions (e.g. 0.0140 year ${ }^{-1} \mathrm{~km}^{-2}$ in Hoces del Riaza and 0.0064 year $^{-1} \mathrm{~km}^{-2}$ in Bárdenas Reales; WWF/Adena, 2008, Cortés-Avizanda et al., 2009). Although discrepancies in the detection of poisoning events between areas may potentially account for these differences, the low figures in our study area could be also related to the lack of small hunting preserves; illegal control of predators on such properties has been highlighted as the main cause of Egyptian vulture poisoning in Spain (Hernández \& Margalida, 2009). Poisoning events have not been highlighted as a significant factor in the abandonment of Egyptian vulture territories in the study area (Mateo-Tomás \& Olea, 2010), in contrast to their apparent impact at a national scale (Carrete et al., 2007). Nonetheless, despite having relatively low rates of poisoning compared to other parts of Spain, the use of poison needs to be controlled, particularly in the SE sector, which had the highest number of poisoned Egyptian vultures and a negative population trend, to guarantee the long-term viability of the population.

The decline in food availability is another critical threat to many European Egyptian vulture populations (BirdLife International, 2008b). The extensive system of livestock rearing, together with the complex topography of our study area, make it difficult to collect carcasses from the field, a requirement of new European sanitary regulations (Olea \& Mateo-Tomás, 2009). Therefore, although these regulations are likely to affect scavengers (Hartasánchez et al., 2006), the situation in our study area may not be as serious as that reported in other areas with intensive farming activity (Camiña, 2007). Moreover, the presence of the carcasses of freely roaming livestock could reduce the high dependence that the species has on muladares (i.e. supplementary feeding stations) in other regions (Carrete et al., 2007). Feeding on carcasses from freely roaming livestock also 
minimizes the risk to vultures of intoxication and disease resulting from veterinary drug ingestion (Blanco et al., 2009). However, food shortages could affect scavengers in the study area in the near future because of the abandonment of extensive livestock production (especially of sheep and goats). This traditional form of production is believed to be the main factor favouring the persistence of Egyptian vultures in the study area (Mateo-Tomás \& Olea, 2010).

In Europe the rapid development of wind farms is threatening soaring birds, including the Egyptian vulture (BirdLife International, 2008b). In Spain it has been suggested that these structures may have a serious negative impact on the population viability of Egyptian vultures (Carrete et al., 2009). Although no Egyptian vultures have been reported as dying from collision with wind turbines in the study area (Fondo para la Protección de los Animales Salvajes and Plataforma para la Defensa de la Cordillera Cantábrica, pers. comms) the number of affected territories and the number of turbines per territory are likely to increase greatly in the next few years. Sixty-nine (39\%) of the territories in the study area will overlap with wind turbines in the near future, with some territories containing several hundred turbines. The strong negative impact of wind farms on the species (Carrete et al., 2009) means that collision with wind turbines could become an important threat for this population. There is therefore a need for effective surveillance and control measures, such as those implemented in other regions (Carrete et al., 2009).

The high percentage $(65.7 \%)$ of Egyptian vulture territories located within Natura 2000 protected areas could facilitate the conservation of the studied population through better surveillance and control of those activities potentially affecting the species (i.e. poisoning, human disturbance, habitat degradation and wind farms; Carrete et al., 2007, 2009; Zuberogoitia et al., 2008). However, any decrease in food resources (as a consequence of livestock decline, for example) could force Egyptian vultures to forage over larger areas, increasing the impact of threats such as poisoning and collision with wind farms (Cortés-Avizanda et al., 2009).

The relatively low impact of conservation threats such as poisoning, food shortages or collision with wind farms could explain the relatively high quality of Egyptian vulture territories in the Cantabrian Mountains (Grande et al., 2009). Currently the Egyptian vulture population of the NW sector is the only one in the Iberian Peninsula with an official Recovery Action Plan (Decreto 135/2001; BOPA, 2001). This Plan could be a useful tool for implementing actions that will facilitate the conservation of the species. However, this Plan affects only $38 \%$ of the studied breeding population. Implementation of conservation actions and plans and cooperation between the regional administrations are therefore needed to guarantee the conservation of this important Cantabrian population of Egyptian vultures.

\section{Acknowledgements}

We thank J.C. del Moral for access to the 2nd and 3rd Spanish surveys of Egyptian vultures and F. Jubete and Parque Nacional de Picos de Europa who provided information about nesting places and breeding parameters. Fondo para la Protección de los Animales Salvajes and Plataforma para la Defensa de la Cordillera Cantábrica provided data on wind farms. J. Tomás, J. and J.A. Herrero, J. Saiz, J. Gómez, M. Gordaliza, S. Bayón, L. Díaz and F. Carcedo provided field assistance. X. Martín, E. Gómez and the Environmental Agents of Junta de Castilla y León in Palencia participated in the census in Palencia, and J. Fernández, Uda, Iñaki and M.A. López collaborated in the census in León during 2008. We thank all the farmers who kindly answered our questions and the Veterinary Units of Junta de Castilla y León. PM-T was supported by a PhD scholarship from the Spanish Ministerio de Educación y Ciencia. IE University partially funded this study.

\section{References}

Benito, J.L., González-Quirós, P. \& Del Campo, J.C. (1997) Seguimiento de la población de alimoche (Neophron percnopterus) en Asturias, Año 1996. Actas del II Congreso Internacional sobre Aves Carroñeras. Cañizares, Solán de Cabras, Cuenca, Spain.

Bergier, P. \& Cheylan, G. (1980) Statut, succès de reproduction et alimentation du vautour pernoptére Neophron percnopterus en France Mediterranéenne. Alauda, 48, 75-97.

Birdife International (2004) Birds in the European Union: A Status Assessment. BirdLife International, Wageningen, The Netherlands.

Birdife InTERnational (2008a) Neophron percnopterus. In IUCN Red List of Threatened Species v. 2009.2. Http://www.iucnredlist.org [accessed 30 March 2009].

BirdLife International (2008b) Species Action Plan for the Egyptian Vulture Neophron percnopterus in the European Union. BirdLife International, Madrid, Spain.

Blanco, G., Lemus, J.A., Martínez, F., Arroyo, B., GarcíaMontijano, M. \& Grande, J. (2009) Ingestion of multiple veterinary drugs and associated impact on vulture health: implications of livestock carcass elimination practices. Animal Conservation, 12, 571-580.

bopa (Boletín Oficial del Principado de Asturias) (2001) Decreto 135/2001. Plan de manejo del alimoche común (Neophron percnopterus). Boletín Oficial del Principado de Asturias, 294, $15915-15918$.

CAmiña, A. (2007) Muladares para el buitre leonado en el sistema Ibérico: la recogida de cadáveres afecta al éxito reproductor de la especie. Quercus, 261, 22-27.

Carrete, M., Grande, J.M., Tella, J.L., Sanchez-Zapata, J.A., Donázar, J.A., Diaz-Delgado, R. \& Romo, A. (2007) Habitat, human pressure, and social behaviour: partialling out factors affecting large-scale territory extinction in an endangered vulture. Biological Conservation, 136, 143-154.

Carrete, M., Sánchez-Zapata, J.A., Benítez, J.R., Lobón, M. \& DonÁZAR, J.A. (2009) Large scale risk-assessment of wind-farms on population viability of a globally endangered long-lived raptor. Biological Conservation, 142, 2454-2961. 
COA (Cordinadora Ornitolóxica d’Asturies) (2004) Censo de alimoche en Asturies 2004. IV Alcuentros Ornitolóxicos Asturianos. Unpublished Report. Cordinadora Ornitolóxica d'Asturies, Gijón, Spain.

Cortés-Avizanda, A., Ceballos, O. \& Donázar, J.A. (2009) Long-term trends in population size and breeding success in the Egyptian vulture (Neophron percnopterus) in northern Spain. Journal of Raptor Research, 43, 43-49.

Cuthbert, R., Green, R.E., Ranade, S., Saràvanan, S., Pain, D.J., Prakash, V. \& Cunningham, A.A. (2006) Rapid population declines of Egyptian vulture (Neophron percnopterus) and red-headed vulture (Sarcogyps calvus) in India. Animal Conservation, 9, 349-354.

Del Moral, J.C. (2009) El alimoche común en España. Población reproductora en 2008 y método de censo. SEO/BirdLife, Madrid, Spain.

Del Moral, J.C. \& Martí, R. (2002) El alimoche común en España y Portugal. I Censo Coordinado. Año 200o. Monografía no. 8. SEO/ BirdLife, Madrid, Spain.

DonÁzar, J.A. (1993) Los buitres ibéricos: Biología y conservación. Eds Reyero, Madrid, Spain.

Donázar, J.A. (2004) Alimoche común Neophron percnopterus. In Libro Rojo de las Aves de España (eds A. Madroño, C. González \& J.C. Atienza), pp. 166-167. Dirección General para la BiodiversidadSEO/BirdLife, Madrid, Spain.

Fombellida, I., Gómez, J. \& Saiz, J. (2008) Seguimiento de las rapaces rupícolas en Cantabria (2007 y 2008): Alimoche, Buitre leonado, Águila perdicera, Águila real y Halcón peregrino. Unpublished Report. Mustela S.C. para la Dirección General de Biodiversidad del Gobierno de Cantabria, Torrelavega, Spain.

García-Ripollés, C. \& López-López, P. (2006) Population size and breeding performance of Egyptian vultures (Neophron percnopterus) in eastern Iberian Peninsula. Journal of Raptor Research, 40, 217-221.

Grande, J.M. (2006) Factores Limitantes Antrópicos y Naturales de Poblaciones de Aves Carroñeras: El Caso del Alimoche (Neophron percnopterus) en el Valle del Ebro. $\mathrm{PhD}$ thesis, University of Seville, Seville, Spain.

Grande, J.M., Serrano, D., Tavecchia, G., Carrete, M., Ceballos, O., Díaz-Delgado, R. et al. (2009) Survival in a long-lived territorial migrant: effects of life-history traits and ecological conditions in wintering and breeding areas. Oikos, 118, 580-590.

Hartasánchez, A., Pando, D., Purroy, F.J. \& Magadán, J.R. (2006) Las carroñas del ganado extensivo vitales para el oso pardo. Quercus, 246, 10-16.
Hernández, M. \& Margalida, A. (2009) Poison-related mortality effects in the endangered Egyptian vulture (Neophron percnopterus) population in Spain. European Journal of Wildlife Research, $55,415-423$.

Jubete, F. (1997) Atlas de las aves nidificantes de la provincia de Palencia. Asociación de Naturalistas Palentinos, Palencia, Spain.

Liberatori, F. \& Penteriani, V. (2001) A long-term analysis of the declining population of the Egyptian vulture in the Italian peninsula: distribution, habitat preference, productivity and conservation implications. Biological Conservation, 101, 381-389.

Martí, R. \& Del Moral, J.C. (2003) Atlas de las aves reproductoras de España. Dirección General de Conservación de la NaturalezaSociedad Española de Ornitología, Madrid, Spain.

Mateo-Tomás, P. \& Olea, P.P. (2009) Combining scales in habitat models to improve conservation planning: a case study of an endangered vulture. Acta Oecologica, 35, 489-498.

Mateo-Tomás, P. \& Olea, P.P. (2010) Diagnosing the causes of territory abandonment by the Endangered Egyptian vulture Neophron percnopterus: the importance of traditional pastoralism and regional conservation. Oryx, 44, 424-433.

Olea, P.P. \& Mateo-Tomás, P. (2009) The role of traditional farming practices in ecosystem conservation: the case of transhumance and vultures. Biological Conservation, 142, 1844-1853.

Perea, J.L., Morales, M. \& Velasco, J. (1990) El Alimoche Neophron percnopterus en España. ICONA, Colección Técnica, Madrid, Spain.

WWF/Adena (2008) Proyecto de conservación y seguimiento del alimoche en las Hoces del Río Riaza (Segovia). 2000-2007. Http:// www.wwf.es/que_hacemos/refugio_de_montejo/publicaciones/ [accessed 2 April 2009].

Zuberogoitia, I., Zabala, J., Martínez, J. \& Azcona, A. (2008) Effect of human activities on Egyptian vulture breeding success. Animal Conservation, 11, 313-320.

\section{Biographical sketches}

Patricia Mateo-Tomás researches the conservation and management of vultures and she is currently studying the impacts of traditional human activities on the conservation of biodiversity. Pedro P. Olea carries out conservation biology research with a particular interest in birds. He is currently leading a multidisciplinary team focused on biodiversity conservation, analysing the impact of human activities on ecosystem conservation. ISIDORO FombELLIDA is an environmental consultant. 